\title{
Local head loss caused in connections used in micro-irrigation systems
}

\author{
Wagner W. Á. Bombardelli' ${ }^{1}$, Antonio P. de Camargo², José A. Frizzone ${ }^{1}$, \\ Rogério Lavanholi ${ }^{1} \&$ Hermes S. da Rocha ${ }^{3}$ \\ ${ }^{1}$ Universidade de São Paulo/Escola Superior de Agricultura “Luiz de Queiroz", Piracicaba, SP, Brasil. E-mail: wavila@usp.br (Corresponding author) -
ORCID: 0000-0002-5939-5524; frizzone@usp.br - ORCID: 0000-0002-4251-1496; rogeriolavanholi@usp.br - ORCID: 0000-0002-9142-4380
${ }^{2}$ Universidade Estadual de Campinas/Faculdade de Engenharia Agrícola, Campinas, SP, Brasil. E-mail: apcpires@unicamp.br - ORCID: 0000-0001-5164-2634
${ }^{3}$ Universidade Federal dos Vales do Jequitinhonha e Mucuri/Instituto de Ciências Agrárias, Unaí, MG, Brasil. E-mail: hermessrocha@gmail.com - ORCID:
0000-0003-2389-8776
}

\begin{abstract}
Information about local head loss caused by connections employed in micro-irrigation systems is hard to be found in literature. The objective of this research was to experimentally determine the local head losses in connections commonly used in micro-irrigation and propose mathematical models using the theorem of Buckingham. The methodology of tests was based on international standards. The tests were carried out under controlled inlet pressure, at $150 \mathrm{kPa}$, and five to ten units of each connection model were tested. The curves relating flow and head losses were drawn based on 15 flow conditions, obtained under increase and decrease of flow rate. For each condition, 30 points were collected resulting in a sample size of 900 points in each test. For each connection model evaluated, the following information was obtained: curves of local head loss as a function of flow rate and of local head loss coefficient $\left(\mathrm{K}_{\mathrm{L}}\right)$. The obtained values of $\mathrm{K}_{\mathrm{L}}$ ranged from 2.72 to 24.16 , which become constant for Reynolds number higher than 10,000. The sensitivity of the coefficient related to a ratio of the internal sections in the connections was also verified. The flow exponents presented values close to the one applied by the Darcy-Weisbach equation $(m=2)$. The models developed for the connections presented a satisfactory performance.
\end{abstract}

Key words: hydraulics, dimensional analysis, Buckingham Pi theorem

\section{Perda de carga localizada em conexões utilizadas em sistemas de microirrigação}

RESUMO: Informações sobre perda de carga localizada em conexões utilizadas em sistemas de microirrigação são difíceis de serem encontradas na literatura. O objetivo desta pesquisa foi determinar experimentalmente as perdas de carga localizada em conexões comumente empregadas nesses sistemas e propor modelos matemáticos utilizando o teorema de Buckingham. A metodologia dos ensaios foi baseada em recomendações de normas técnicas internacionais. Os ensaios foram realizados sob pressão de entrada controlada em $150 \mathrm{kPa}$, com cinco a dez unidades testadas para cada modelo de conexão. As curvas relacionando vazão e perda de carga localizada foram plotadas com base em 15 condições de vazão, obtidas sob incremento e decréscimo de vazão. Para cada condição, foram coletados 30 pontos, resultando num conjunto de 900 registros de dados a cada ensaio. Em cada modelo de conexão avaliado, foram obtidas as seguintes informações: curvas de perda de carga localizada em função da vazão e do coeficiente de perda de carga localizada $\left(\mathrm{K}_{\mathrm{L}}\right)$. Os valores de $\mathrm{K}_{\mathrm{L}}$ variaram de 2,72 a 24,16, o qual tornar-se constante para um número de Reynolds acima de 10000 . Verificouse também a sensibilidade do coeficiente KL relacionado com a proporção das seções internas nas conexões. Os expoentes de vazão apresentaram valores próximos ao que é aplicado pela equação de Darcy-Weisbach $(\mathrm{m}=2)$. Os modelos matemáticos desenvolvidos para as conexões apresentaram desempenho satisfatório.

Palavras-chave: hidráulica, análise dimensional, teorema Pi de Buckingham 


\section{INTRODUCTION}

Omitting local head losses in projects of micro-irrigation systems may substantially compromise their operational characteristics and performance. Increments of 5 to $32 \%$ have been reported in the total energy loss caused by the protrusion of online emitters in 13- and 25-mm-diameter polyethylene pipes (Al-Amoud, 1995). Neglecting the effect of head losses may induce errors of up to $25 \%$ in the estimation of diameters and $7 \%$ in the maximum length of laterals (Yildirim, 2007). Considering simulations of two models of pipes with in-line and on-line emitters, head losses contributed with 6.4 and $49.5 \%$ of the total energy loss in the project of lateral lines (Provenzano \& Pumo, 2004). In another study, total head loss increased from 24.5 to $50.8 \%$ due to local head losses caused by non-coaxial drippers inserted in polyethylene pipes (Rettore Neto et al., 2009).

There is a direct proportion between local head loss and kinetic energy, and that is expressed by a local head loss coefficient $\left(\mathrm{K}_{\mathrm{L}}\right)$. This value is obtained experimentally, being specific for each type of connection or accessory. However, technical information on connections and accessories, when available, is out of date because of the continuous improvement of production technologies (Kotowski et al., 2011) and the changes in the geometry of pieces, which can cause discrepancies compared to the values suggested in hydraulic tables (Prado, 2015).

This study aimed to experimentally determine local head losses caused by some connections commonly used in microirrigation systems and propose mathematical models, obtained by dimensional analysis and Buckingham Pi theorem.

\section{Material ANd Methods}

The experimental procedures were carried out in the Laboratory of Irrigation Material Tests (22 $42^{\prime}$ S; $47^{\circ} 37^{\prime} \mathrm{W}$ ) of the Departamento de Engenharia de Biosistemas da Escola Superior de Agricultura Luiz de Queiroz - ESALQ/USP in Piracicaba, SP state, Brazil. The test bench used operates in a hydraulically closed circuit, supplied by a tank connected to a motor pump set. The arrangement of the instruments and of the test bench itself was based on international standards ISO/ TR 15155; ISO 9644 (ISO, 2005, 2008).

Flow rate was monitored using an electromagnetic flowmeter, with resolution of $0.01 \mathrm{~m}^{3} \mathrm{~h}^{-1}$, measuring range from 0 to $4 \mathrm{~m}^{3} \mathrm{~h}^{-1}$ and expanded uncertainty of $0.5 \%$ of the full scale (FS). This instrument was installed upstream the connection under evaluation. The pressure drop due to local head loss was measured by a differential pressure transmitter, with resolution of $0.01 \mathrm{kPa}$, measuring range from 1 to $100 \mathrm{kPa}$, precision of $0.075 \% \mathrm{FS}$, as informed by the manufacturer. Water temperature was monitored by a temperature transmitter, with resolution of $0.1{ }^{\circ} \mathrm{C}$, measuring range from 0 to $50{ }^{\circ} \mathrm{C}$, with uncertainty of $0.5 \%$ FS. Test pressure was monitored by a pressure transmitter, with resolution of 0.001 bar, measuring range from 0 to 5 bar, with uncertainty of $0.1 \%$ FS.

Test pressure was adjusted by an electronically controlled proportional valve $(1 / 2$ inch), installed upstream the test connection. The valve drive control (VDC) is operated through electrical signals in the range from 2 to $10 \mathrm{VDC}$. The motor pump rotation as well as the test pressure were controlled by a variable frequency drive. The test pressure was controlled by a Proportional-Integrative-Derivative (PID) controller. The use of PID controller aims to ensure accuracy and stability in the control of test pressures. Details on the test bench and its validation are presented by Bombardelli et al. (2017) and Bombardelli (2018).

The connections tested are produced by the Brazilian Company RSB Plásticos Ltda. and are used in micro-irrigation systems. The connection models evaluated are used in pipes with nominal diameter of 13 and $16 \mathrm{~mm}$. Figure 1 illustrates the models of connections, which were grouped into the following categories: union connectors (ID: 0038 and 0081, Figure 1A), start connectors (ID: 0046 and 0057, Figure 1B), union valves (ID: 0151 and 0153, Figure 1C) and start valves (ID: 0150 and 0152, Figure 1D).

Local head loss assumes a close relationship with the geometric characteristics of the singularities (Azevedo Neto \& Fernández y Fernández, 2015). Figure 2 illustrates the longitudinal cut of the tested connections, naming their dimensions.

The geometric characteristics of the pieces were obtained using a digital caliper, with resolution of $0.01 \mathrm{~mm}$ and measuring ranging from 0 to $150 \mathrm{~mm}$, by sampling 10 units. In the categories of pieces belonging to the group of valves, the dimensions of the narrowest internal section (throat) were measured using an optical profile projector. Table 1 presents the dimensions of the tested groups.

The local head loss caused by the flow through the evaluated connections was measured with a differential

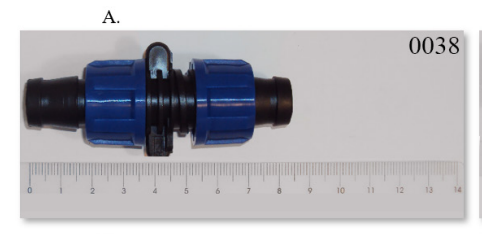

B.

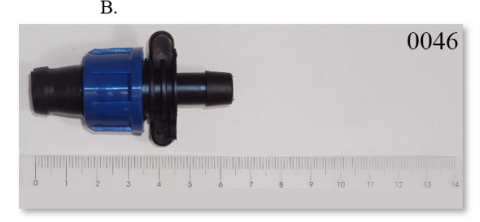

Figure 1. Models of connections tested, grouped by (A) union connectors, (B) start connectors, (C) union valves and (D) start valves
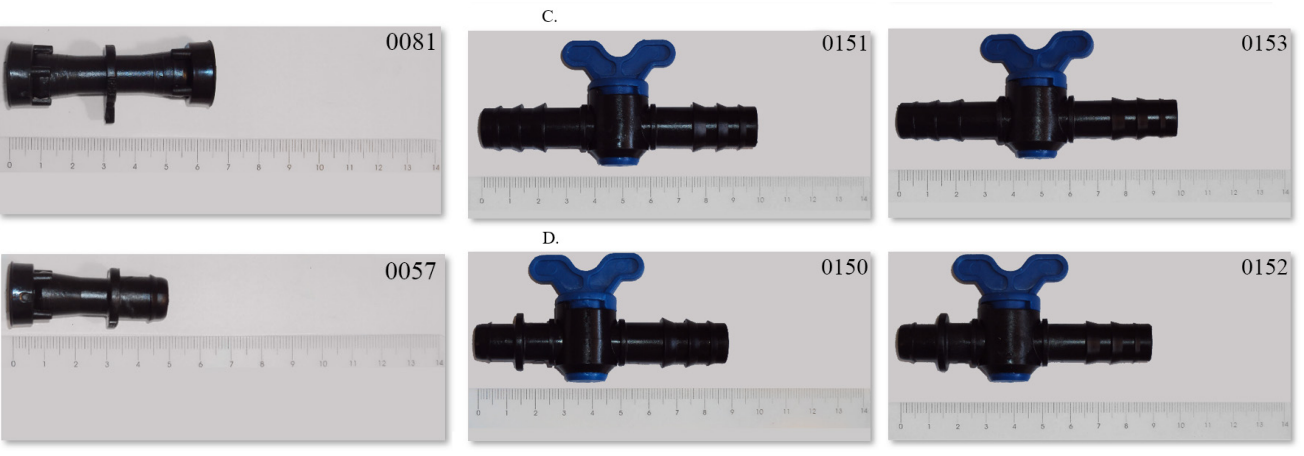

R. Bras. Eng. Agríc. Ambiental, v.23, n.7, p.492-498, 2019. 
A. 0038

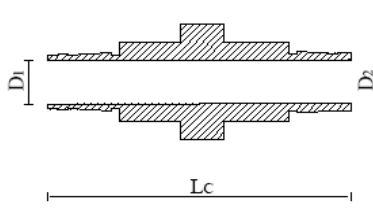

0081

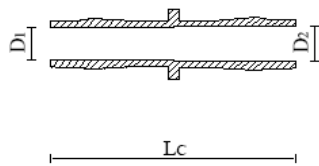

B.
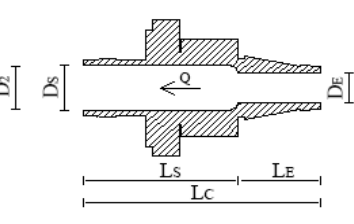

0057

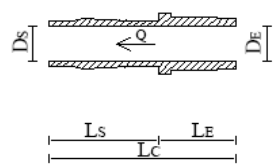

C.

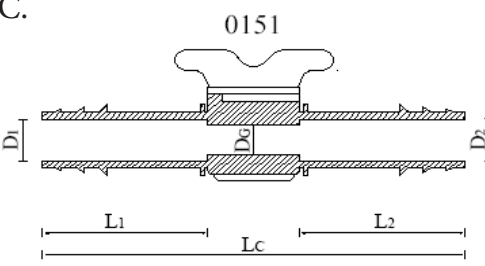

0153

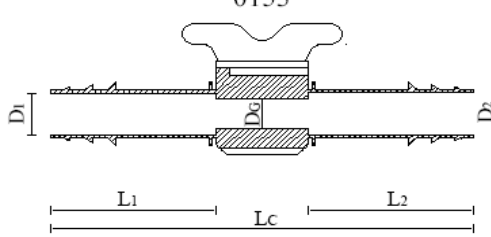

D.
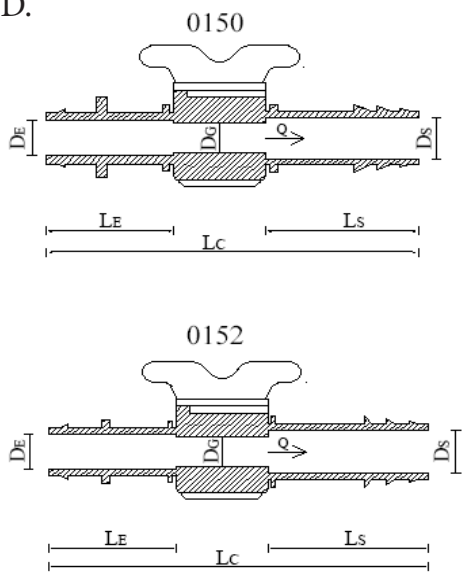

Where the fittings (labeled by his ID) are arranged by classes in the columns, which: (A) union connectors [0038, 0081]; (B) start connectors [0046, 0057]; (C) union valves [0151, 0153], and; (D) start valves [0150, 0152]. The dimensions are represented as, DE or D1: Inlet internal diameter; DS or D2: Outlet internal diameter; DG: Throat diameter; LE or L1: Inlet length; LS or L2: Outlet length, and; LC: Total length of the connection. In case of start connectors/valve, the direction of the water flow (Q) is indicated by the arrow below

Figure 2. Longitudinal cut of the tested connections representing the characteristic dimensions

Table 1. Mean (x) and standard deviation (s) of the characteristic dimensions of the evaluated models of connections

\begin{tabular}{|c|c|c|c|c|c|c|}
\hline \multirow{2}{*}{ ID } & $D_{E}$ or $D_{1}$ & $\mathrm{D}_{\mathrm{s}}$ or $\mathrm{D}_{2}$ & $D_{G}$ & $L_{E}$ or $L_{1}$ & $L_{S}$ or $L_{2}$ & $L_{c}$ \\
\hline & \multicolumn{6}{|c|}{$x(\mathrm{~mm}) \pm \mathrm{s}(\mathrm{mm})$} \\
\hline 0038 & $11.74 \pm 0.06$ & $12.17 \pm 0.05$ & - & - & - & $79.99 \pm 0.10$ \\
\hline 0046 & $7.95 \pm 0.03$ & $12.36 \pm 0.03$ & - & $21.63 \pm 0.23$ & $40.83 \pm 0.27$ & $62.46 \pm 0.07$ \\
\hline 0057 & $9.64 \pm 0.02$ & $9.66 \pm 0.03$ & - & $18.47 \pm 0.22$ & $30.77 \pm 0.26$ & $49.24 \pm 0.10$ \\
\hline 0081 & $9.66 \pm 0.05$ & $9.19 \pm 0.02$ & - & - & - & $64.68 \pm 0.12$ \\
\hline 0150 & $9.51 \pm 0.04$ & $11.59 \pm 0.01$ & $7.55 \pm 0.16$ & $33.44 \pm 0.48$ & $43.14 \pm 0.80$ & $89.99 \pm 0.12$ \\
\hline 0151 & $11.53 \pm 0.04$ & $11.64 \pm 0.01$ & $7.65 \pm 0.39$ & $43.67 \pm 0.97$ & $43.17 \pm 1.41$ & $100.56 \pm 0.09$ \\
\hline 0152 & $9.46 \pm 0.02$ & $11.61 \pm 0.06$ & $7.59 \pm 0.08$ & $33.48 \pm 0.89$ & $42.39 \pm 0.52$ & $90.06 \pm 0.10$ \\
\hline 0153 & $11.50 \pm 0.12$ & $11.58 \pm 0.11$ & $7.98 \pm 0.11$ & $43.16 \pm 0.62$ & $43.35 \pm 0.65$ & $100.37 \pm 0.05$ \\
\hline
\end{tabular}

ID - Identification number; $\mathrm{D}_{\mathrm{E}}$ or $\mathrm{D}_{1}$ - Inlet internal diameter; $\mathrm{D}_{\mathrm{S}}$ or $\mathrm{D}_{2}$ - Outlet internal diameter; $\mathrm{D}_{\mathrm{G}}$ - Throat diameter; $\mathrm{L}_{\mathrm{E}}$ or $\mathrm{L}_{1}$ - Inlet length; $\mathrm{L}_{\mathrm{S}}$ or $\mathrm{L}_{2}$ - Outlet length, and; $\mathrm{L}_{\mathrm{C}}$ - Total length of the connection

pressure transmitter, by installing pressure taps upstream and downstream in the connection (Bombardelli et al., 2017). The distance of the pressure taps from the connection is an important detail in this type of tests, because very short distances may cause excessive instability in the indications of differential pressure, whereas very long distances cause considerable major loss. The standard ISO 9644 (ISO, 2008), for the test of irrigation valves, recommends that pressure taps are installed at distances corresponding to two pipe diameters upstream the connection and 10 diameter downstream the connection. These distances were adopted in all tests, because this technical information is the closest one to the test conditions.

Given the distances of the pressure taps, preliminary estimates of the major loss in the segment where the connection was installed were carried out. Local head loss under each test condition was obtained by subtracting the major loss from the total head loss.

For each model of connection, 5 to 10 units of a same lot were tested. The models of connections were tested with fully open angle, as recommended by the standard ISO 9644 (ISO, 2008). A flow-pressure drop curve with at least 5 flow conditions is recommended ISO 9644 (ISO, 2008). The curves relating flow rate and local head loss were constructed with at least 15 pairs of points, under controlled inlet pressure of $150 \mathrm{kPa}$, and also under increasing and decreasing pressure conditions to include possible effects of hysteresis in the control and measurement system. Since the data were electronically acquired, for each test pressure 30 readings were taken by the transmitters, in order to increase the reliability of the measurements. Additionally, water temperature was continuously monitored during the tests.

From the experimental data, power-law equations were fitted for each local head loss. For each model of connection evaluated, the following data were obtained: power-law equation of local head loss as a function of flow rate; and local head loss coefficient $\left(\mathrm{K}_{\mathrm{L}}\right)$. Friction factor " $\mathrm{f}$ " was calculated using Eq. 1 (Swamee, 1993), adopting Reynolds number estimated by an average flow velocity of $1.50 \mathrm{~m} \mathrm{~s}^{-1}$ with water temperature of $20{ }^{\circ} \mathrm{C}$ and polyethylene pipe roughness of $8.116 \mu \mathrm{m}$ (Rocha et al., 2017).

$$
\mathrm{f}=\left\{\left(\frac{64}{\mathrm{R}_{\mathrm{e}}}\right)^{8}+9.5\left[\ln \left(\frac{\varepsilon}{3.7 \mathrm{D}_{\mathrm{L}}}+\frac{5.74}{\mathrm{R}_{\mathrm{e}}^{0.9}}\right)-\left(\frac{2500}{\mathrm{R}_{\mathrm{e}}}\right)^{6}\right]^{-16}\right\}^{0.125}
$$

where:

f - friction factor, dimensionless;

$\mathrm{R}_{\mathrm{e}} \quad$ - Reynolds number, dimensionless;

$\varepsilon \quad$ - average roughness, $\mathrm{m}$; and,

$\mathrm{D}_{\mathrm{L}} \quad$ - internal diameter of lateral line, $\mathrm{m}$.

The combined use of theoretical and experimental methods is usually required in applications involving hydraulic and fluid mechanics (Zitterell et al., 2013; Vilaça et al., 2017). Dimensional analysis is a useful technique to solve problems related to these fields because it allows grouping and reducing 
the number of variables necessary for modeling physical processes and it is also useful for developing prediction models (Vilaça et al., 2017).

The present study used the dimensional analysis based on Buckingham Pi theorem (Buckingham, 1914) and on the method of repeated variables (Freitas et al., 2015), following the recommendations proposed by Munson et al. (2013) and Fox et al. (2011). Dimensionless $\Pi$ groups were formed (Eq. 2) based on the number of variables $(\mathrm{k})$ which describe the process and on the number of dimensions referencing these variables (r). For each group of connections, the number of dimensionless groups (Pi terms), $\mathrm{n}$, was obtained by the subtraction $\mathrm{k}-\mathrm{r}$.

$$
\Pi_{1}=\phi\left(\Pi_{2}, \Pi_{3}, \ldots, \Pi_{\mathrm{n}}\right)
$$

For any of the cases analyzed in the sequence, local head loss was assumed to be influenced by physical properties of water (density and dynamic viscosity), flow velocity, pipe diameter and by geometric characteristics of the evaluated piece (Eq. 3 ). Thus, the physical process related to the local head loss involves variables characterized by three basic dimensions ( $r$ =3), which are MLT (mass, length and time).

$$
\begin{aligned}
\Delta \mathrm{p}_{\mathrm{c}}= & \left(\rho, \mu, \mathrm{V}_{\mathrm{L}}, \mathrm{D}_{\mathrm{L}},\right. \text { geometric characteristics } \\
& \text { of the hydraulic connection })
\end{aligned}
$$

where:

$\Delta \mathrm{p}_{\mathrm{c}}$ - pressure drop due to the connection, $\mathrm{Pa}$;

$\rho \quad$ - water density, $\mathrm{kg} \mathrm{m}^{-3}$;

$\mu \quad$ - water dynamic viscosity, Pa s; and,

$\mathrm{V}_{\mathrm{L}}$ - average flow velocity in the lateral line, $\mathrm{m} \mathrm{s}^{-1}$.

The Pi terms defined in the sequence were obtained by combining the repeated variables $V_{L}, D_{L}$ and $\rho$ with the remaining variables. The dimensionless groups proposed for the modeling of start connectors were based on the study of Vilaça et al. (2017), according to Eq. 4. Union connectors had a simpler geometry and the inlet and outlet diameter terms were reduced to a single term of the internal diameter of the piece, and the lengths were expressed only by the total length of the piece (Eq. 5).

$$
\frac{\Delta p_{c}}{\rho V_{L}^{2}}=\varnothing\left(\frac{\rho V_{L} D_{L}}{\mu}, \frac{D_{E}}{D_{L}}, \frac{D_{S}}{D_{L}}, \frac{L_{E}}{D_{L}}, \frac{L_{S}}{D_{L}}\right)
$$

where:

$\mathrm{D}_{\mathrm{E}} \quad$ - inlet internal diameter, $\mathrm{m}$;

$\mathrm{D}_{\mathrm{S}} \quad$ - outlet internal diameter, $\mathrm{m}$;

$\mathrm{L}_{\mathrm{E}} \quad$ - inlet length of the connections, $\mathrm{m}$; and,

$\mathrm{L}_{\mathrm{S}} \quad$ - outlet length of the connection, $\mathrm{m}$.

$$
\frac{\Delta \mathrm{p}_{\mathrm{c}}}{\rho \mathrm{V}_{\mathrm{L}}^{2}}=\varnothing\left(\frac{\rho \mathrm{V}_{\mathrm{L}} \mathrm{D}_{\mathrm{L}}}{\mu}, \frac{\mathrm{D}_{\mathrm{i}}}{\mathrm{D}_{\mathrm{L}}}, \frac{\mathrm{L}_{\mathrm{C}}}{\mathrm{D}_{\mathrm{L}}}\right)
$$

where:

$\mathrm{D}_{\mathrm{i}} \quad$ - average internal diameter of union connectors, $\mathrm{m}$; and,

$\mathrm{L}_{\mathrm{C}} \quad$ - total length of the connection, $\mathrm{m}$.
For union valves (Eq. 6), six dimensionless groups were proposed, including a relationship of the throat internal diameter with pipe diameter $\left(\mathrm{D}_{\mathrm{G}} / \mathrm{D}_{\mathrm{L}}\right)$ and its corresponding length $\left(\mathrm{L}_{\mathrm{G}}\right)$ deduced by the difference of $\mathrm{L}_{\mathrm{C}}$ with $\mathrm{L}_{1}$ and $\mathrm{L}_{2}$. Lastly, for the valves of start connectors (Eq. 7), all expected dimensionless intervals were considered, which led to an eight-term expression.

$$
\frac{\Delta p_{c}}{\rho V_{L}^{2}}=\varnothing\left(\frac{\rho V_{L} D_{L}}{\mu}, \frac{D_{i}}{D_{L}}, \frac{D_{G}}{D_{L}}, \frac{L_{C}}{D_{L}}, \frac{L_{G}}{D_{L}}\right)
$$

where:

$\mathrm{D}_{\mathrm{G}}$ - throat diameter, $\mathrm{m}$; and,

$\mathrm{L}_{\mathrm{G}}$ - throat length, $\mathrm{m}$.

$$
\frac{\Delta p_{c}}{\rho V_{L}^{2}}=\varnothing\left(\frac{\rho V_{L} D_{L}}{\mu}, \frac{D_{E}}{D_{L}}, \frac{D_{S}}{D_{L}}, \frac{D_{G}}{D_{L}}, \frac{L_{E}}{D_{L}}, \frac{L_{S}}{D_{L}}, \frac{L_{G}}{D_{L}}\right)
$$

A power-law multiple regression equation (Eq. 8) was fitted to each of the data sets using the Least Squares Method. This form of equation has been successfully used to model similar hydraulic phenomena (Vekariya et al., 2010; Zitterell et al., 2013; Perboni et al., 2015; Vilaça et al., 2017).

$$
\Pi_{1}=\beta_{1} \Pi_{2}^{\beta_{2}} \Pi_{3}^{\beta_{3}} \ldots \Pi_{\mathrm{n}}^{\beta_{\mathrm{n}}}
$$

where:

$\beta_{\mathrm{n}} \quad$ - empirical coefficient, dimensionless.

The models were assessed by the root mean square error (RMSE) and analysis of cumulative frequency distribution of errors. RMSE is commonly used and represents the dispersion between the observed values and those estimated by mathematical models (Willmott et al., 2012; Ali \& Abustan, 2014). The analysis of cumulative frequency distribution of errors is also useful for estimating errors of prediction because it provides a distribution of the relative errors associated with the cumulative frequency.

The experimental data set corresponding to each group of connections was randomized and segmented into two subgroups: calibration data (70\% of the data) and validation data ( $30 \%$ of the data).

The mathematical models presented were simplified considering the gravitational acceleration as $9.81 \mathrm{~m} \mathrm{~s}^{-2}$ and water temperature of $20^{\circ} \mathrm{C}$, and are representative for the range of lateral line diameter $\left(D_{L}\right)$ from 13.70 to $16.39 \mathrm{~mm}$. The model for start connectors was compared with the simplified model (Eq. 9) proposed by Vilaça et al. (2017), which was calibrated for $3026 \leq \mathrm{Re} \leq 94536 ; 0.4147 \leq \mathrm{D}_{\mathrm{E}} / \mathrm{D}_{\mathrm{L}} \leq 0.7672 ; 0.5721 \leq \mathrm{D}_{\mathrm{S}} /$ $\mathrm{D}_{\mathrm{L}} \leq 0.8538 ; 1.9435 \leq \mathrm{L}_{\mathrm{C}} / \mathrm{D}_{\mathrm{L}} \leq 4.3765$. The obtained data set is met for the conditioned input ranges of both models. The input terms of Eq. 9 are $\mathrm{hf}_{\mathrm{L}}(\mathrm{m}) ; v\left(\mathrm{~m}^{2} \mathrm{~s}^{-1}\right) ; \mathrm{V}_{\mathrm{L}}\left(\mathrm{m} \mathrm{s}^{-1}\right) ; \mathrm{D}_{\mathrm{L}}(\mathrm{m}) ; \mathrm{D}_{\mathrm{E}}(\mathrm{m})$.

$$
\mathrm{hf}_{\mathrm{L}}=0.0190 \frac{\mathrm{V}_{\mathrm{L}}^{2.0632} \mathrm{D}_{\mathrm{L}}^{4.5565}}{v^{0.0632} \mathrm{D}_{\mathrm{E}}^{4.4933}}
$$


where:

$v \quad$ - water kinematic viscosity, $\mathrm{m}^{2} \mathrm{~s}^{-1}$.

\section{Results AND Discussion}

Figure 3 illustrates the collected data and the analyses carried out for the connection ID: 0046, which is one of the models of start connector evaluated and that showed the highest indicators of local head loss. The same procedure was adopted for all connections evaluated. Figure $3 \mathrm{~A}$ presents the local head loss in function of flow rate. This curve is obtained by the difference between total head loss and major loss, and a power-law equation was fitted to this data. Figure $3 \mathrm{~B}$ presents the local head loss as a function of kinetic head, and the local head loss coefficient $\left(\mathrm{K}_{\mathrm{L}}\right)$ corresponds to the angular coefficient of the line illustrated in this figure. Lastly, Figure 3C indicates how much $\mathrm{K}_{\mathrm{L}}$ varies as the Reynolds number increases.

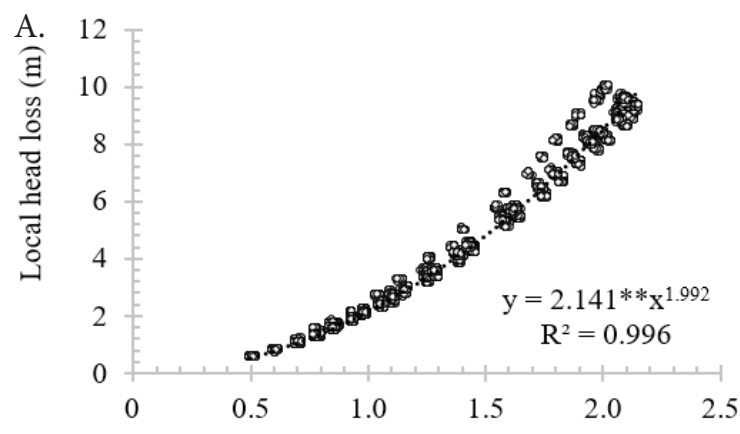

Flow rate $\left(\mathrm{m}^{3} \mathrm{~h}^{-1}\right)$

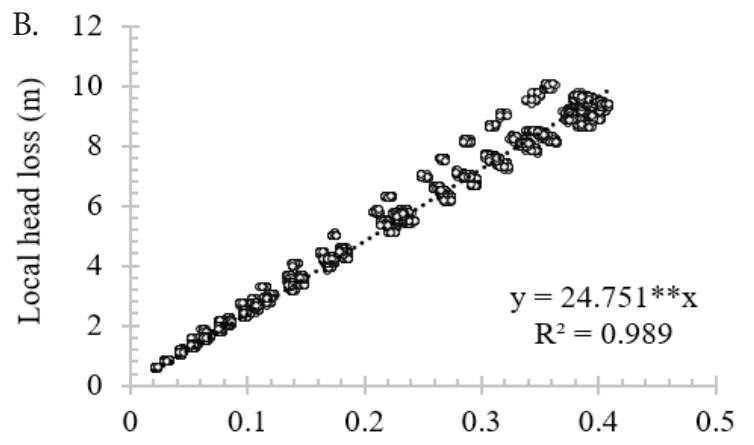

Kinetic head (m)

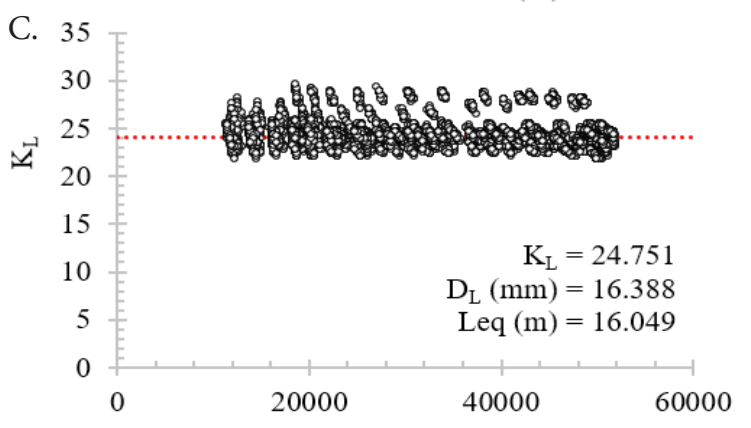

Reynolds number

$\mathrm{K}_{\mathrm{L}}$ - Local head loss coefficient (-); $\mathrm{D}_{\mathrm{L}}$ - Internal diameter of lateral line (mm); Leq Equivalent length to measure local head loss $(\mathrm{m}){ }^{* *}$ Significant at 0.01 probability level by t-test

Figure 3. Experimental data obtained for the model 0046: (A) local head loss as a function of flow rate; (B) local head loss as a function of kinetic head; (C) coefficient $\mathrm{K}_{\mathrm{L}}$ as a function of Reynolds number
$\mathrm{K}_{\mathrm{L}}$ data usually become stable from a Reynolds number of approximately 10,000, as observed by Rettore Neto et al. (2009) and Zitterell et al. (2009). Cardoso (2014) observed stable values of $K_{L}$ for Reynolds number of 20,000 , studying pipe-connection sets. Above these values of Reynolds number, the effect of viscosity forces are assumed to be negligible in the flow and the local head loss coefficient $\left(\mathrm{K}_{\mathrm{L}}\right)$ becomes almost exclusively dependent on the geometric characteristics of the piece (Rettore Neto et al., 2009). One should pay attention to the impact caused by the increment in the kinetic head. For instance, if the velocity in the line is $2 \mathrm{~m} \mathrm{~s}^{-1}$ (kinetic head of approximately $0.2 \mathrm{~m}$ ) there will be head loss of almost $5 \mathrm{~m}$, caused by the start connector. This corroborates the fact that the geometry of the irrigation material must be improved in order to reduce these losses. On the other hand, all other models evaluated showed lower values of local head loss, indicating more appropriate shape/geometry (Table 2).

For both pipes tested with reference velocity of $1.50 \mathrm{~m} \mathrm{~s}^{-1}$, the mean, standard deviation and the coefficient of variation were calculated for $K_{L}$ data. Table 2 presents this simple descriptive analysis of the technical data of the lot, in order to demonstrate its sampling variation. The connection 0152 showed higher data dispersion between the units of the same model, perhaps due to irregularities in the narrowest section of the piece (throat) and imperfections in the manufacturing process. Table 2 also presents the power-law equations fitted to local head loss $\left(\mathrm{hf}_{\mathrm{L}}\right)$ data as a function of the flow rate through the lateral path in the piece $(\mathrm{Q})$, where $\mathrm{Q}$ is expressed in $\mathrm{m}^{3} \mathrm{~h}^{-1}$. It can be noted that the exponent applied to the flow rate is close to the coefficient used in the Darcy-Weisbach equation $(m=2)$.

Due to its reduced dimensional characteristics and the existence of successive alterations in the flow section (Vilaça et al., 2017), the local head loss coefficients in micro-irrigation connections assume discrepant values when compared to hydraulic connections of buildings. The minimum and maximum values of average $\mathrm{K}_{\mathrm{L}}$ reached by the evaluated connections are attributed to the models identified as 0038 and 0046. For the $\mathrm{D}_{S} / \mathrm{D}_{\mathrm{E}}$ quotient of their dimensions, the maximum $\mathrm{K}_{\mathrm{L}}$ (ID: 0046) has a ratio of 1.555 , whereas the minimum (ID: 0038) has a ratio of only 1.037 (Table 1 ). The high head loss observed in the piece 0046 is justified by the large expansion in the flow section. In terms of construction,

Table 2. Experimental data of the local head loss curve and $\mathrm{K}_{\mathrm{L}}$ values obtained for the models of connection (UC - Union connector; SC - Start connector; UV - Union valve; SV - Start valve)

\begin{tabular}{|c|c|c|c|c|c|}
\hline \multirow{2}{*}{ ID } & \multirow{2}{*}{$\begin{array}{c}\text { Class/D } D_{L} \\
(\mathrm{~mm})\end{array}$} & \multirow{2}{*}{$\begin{array}{c}\text { Equations of hf } \\
\text { (m) }\end{array}$} & \multicolumn{3}{|c|}{$K_{L}$} \\
\hline & & & $\bar{x}$ & s & CV (\%) \\
\hline 0038 & UC 16 & $0.3 Q^{2.0}$ & 2.719 & 0.151 & 5.554 \\
\hline 0046 & SC 16 & $2.1 Q^{2.0}$ & 24.164 & 1.420 & 5.877 \\
\hline 0057 & SC 13 & $1.0 Q^{2.0}$ & 5.721 & 0.103 & 1.800 \\
\hline 0081 & UC 13 & $0.6 \mathrm{Q}^{2.0}$ & 3.625 & 0.240 & 6.621 \\
\hline 0150 & SV 16 & $2.0 \mathrm{Q}^{2.0}$ & 22.288 & 0.866 & 3.886 \\
\hline 0151 & UV 16 & $1.4 Q^{2.0}$ & 15.776 & 1.131 & 7.169 \\
\hline 0152 & SV 13 & $2.0 Q^{2.0}$ & 11.086 & 1.220 & 11.005 \\
\hline 0153 & UV 13 & $1.5 \mathrm{Q}^{2.0}$ & 8.487 & 0.746 & 8.790 \\
\hline
\end{tabular}

ID - Identification number; $\mathrm{D}_{\mathrm{L}}$ - Internal diameter of lateral line; $\mathrm{hf}_{\mathrm{L}}$ - Local head loss as a function of flow rate (Q) in $\mathrm{m}^{3} \mathrm{~s}^{-1} ; \mathrm{K}_{\mathrm{L}}$ - Local head loss coefficient; $\mathrm{x}$ - Mean of values obtained of $K_{L}$ by group; $s$ - Standard deviation obtained of $K_{L}$ by group, and; CV Coefficient of variation (ratio of $s$ by $\mathrm{x}$ in percentage) 
it would be interesting to design connections in such a way to avoid expansions in the flow section or, in cases where this is necessary, it is essential to design smooth and gradual expansions in order to reduce local head losses.

The mathematical models proposed for the classes of pieces tested are presented hereinafter. These equations can be important for projects of irrigation systems and development of material by industries. For a maximum local head loss allowed in the connection to be designed, the industry can vary the dimensions of the piece to achieve the project goals.

The model proposed for union connectors (Eq. 10) was calibrated for the following ranges: $0.68 \leq \mathrm{V}_{\mathrm{L}}\left(\mathrm{m} \mathrm{s}^{-1}\right) \leq 5.59$; $64.68 \leq \mathrm{L}_{\mathrm{C}}(\mathrm{mm}) \leq 79.99 ; 9.43 \leq \mathrm{D}_{\mathrm{i}}(\mathrm{mm}) \leq 11.95$. These velocity ranges exceed the practical limits recommended for the project of micro-irrigation systems (lower than $2.0 \mathrm{~m} \mathrm{~s}^{-1}$ ) and are only used to calibrate the model and obtain more comprehensive results.

$$
\mathrm{hf}_{\mathrm{L}}=0.156 \frac{\mathrm{V}_{\mathrm{L}}^{2.007} \mathrm{D}_{\mathrm{L}}^{5.087}}{\mathrm{~L}_{\mathrm{C}}^{0.888} \mathrm{D}_{\mathrm{i}}^{4.191}}
$$

where:

$\mathrm{hf}_{\mathrm{L}} \quad$ - local head loss in the connection, $\mathrm{m}$.

The model for start connectors (Eq. 11) was calibrated for the following ranges: $0.66 \leq \mathrm{V}_{\mathrm{L}}\left(\mathrm{m} \mathrm{s}^{-1}\right) \leq 4.11 ; 18.47 \leq \mathrm{L}_{\mathrm{E}}(\mathrm{mm})$ $\leq 21.63 ; 30.77 \leq \mathrm{L}_{\mathrm{S}}(\mathrm{mm}) \leq 40.83 ; 7.95 \leq \mathrm{D}_{\mathrm{E}}(\mathrm{mm}) \leq 9.64 ; 9.66$ $\leq \mathrm{D}_{\mathrm{S}}(\mathrm{mm}) \leq 12.36$.

$$
\mathrm{hf}_{\mathrm{L}}=0.004 \frac{\mathrm{V}_{\mathrm{L}}^{1.995} \mathrm{D}_{\mathrm{L}}^{4.282} \mathrm{D}_{\mathrm{S}}^{0.179} \mathrm{~L}_{\mathrm{S}}^{10.589}}{\mathrm{~L}_{\mathrm{E}}^{14.801} \mathrm{D}_{\mathrm{E}}^{0.254}}
$$

The model for union valves (Eq. 12) was calibrated for the following ranges: $0.76 \leq \mathrm{V}_{\mathrm{L}}\left(\mathrm{m} \mathrm{s}^{-1}\right) \leq 2.26 ; 13.72 \leq \mathrm{L}_{\mathrm{G}}(\mathrm{mm}) \leq$ 13.86; $100.37 \leq \mathrm{L}_{\mathrm{C}}(\mathrm{mm}) \leq 100.56 ; 11.54 \leq \mathrm{D}_{\mathrm{i}}(\mathrm{mm}) \leq 11.58$; $7.65 \leq \mathrm{D}_{\mathrm{G}}(\mathrm{mm}) \leq 7.98$.

$$
\mathrm{hf}_{\mathrm{L}}=0.179 \frac{\mathrm{V}_{\mathrm{L}}^{2.008} \mathrm{D}_{\mathrm{L}}^{3.042}}{\mathrm{D}_{\mathrm{i}}^{0.967} \mathrm{D}_{\mathrm{G}}^{1.849} \mathrm{~L}_{\mathrm{C}}^{0.039} \mathrm{~L}_{\mathrm{G}}^{0.179}}
$$

The model for start valves (Eq. 13) was calibrated for the following ranges: $0.62 \leq \mathrm{V}_{\mathrm{L}}\left(\mathrm{m} \mathrm{s}^{-1}\right) \leq 2.19 ; 33.44 \leq \mathrm{L}_{\mathrm{E}}(\mathrm{mm}) \leq$ $33.48 ; 13.41 \leq \mathrm{L}_{\mathrm{G}}(\mathrm{mm}) \leq 14.20 ; 42.39 \leq \mathrm{L}_{\mathrm{S}}(\mathrm{mm}) \leq 43.14 ; 9.46$ $\leq \mathrm{D}_{\mathrm{E}}(\mathrm{mm}) \leq 9.51 ; 7.55 \leq \mathrm{D}_{\mathrm{G}}(\mathrm{mm}) \leq 7.59 ; 11.59 \leq \mathrm{D}_{\mathrm{S}}(\mathrm{mm})$ $\leq 11.61$.

$$
\mathrm{hf}_{\mathrm{L}}=0.105 \frac{\mathrm{V}_{\mathrm{L}}^{1.971} \mathrm{D}_{\mathrm{L}}^{3.465} \mathrm{~L}_{\mathrm{E}}^{0.067} \mathrm{~L}_{\mathrm{S}}^{0.350}}{\mathrm{D}_{\mathrm{E}}^{0.889} \mathrm{D}_{\mathrm{S}}^{0.762} \mathrm{D}_{\mathrm{G}}^{1.197} \mathrm{~L}_{\mathrm{G}}^{1.063}}
$$

RMSE assumes a value of 0.132 in the model proposed for the union valves, followed by 0.181 in the models of union connector. The value obtained in the model proposed for start connectors was 0.313 and is close to that obtained by Vilaça et al. (2017), who found RMSE of 0.282 through a simplified model to predict local head loss in the lateral path of start connectors. Lastly, the class of start valves showed RMSE of 0.372 .
Figure 4 presents the graphical analysis of the errors for union connectors. Figure 4A compares observed and estimated values of local head loss. Figure $4 \mathrm{~B}$ shows the relative error of the data estimated by the cumulative frequency.

The same process of error analysis was carried out for the class of start connectors, union valves and start valves, and relative errors of up to $10 \%$ were observed respectively at approximately $46.46,63.33$ and $18.95 \%$ of the cumulative frequency of the estimated values.

It was observed that the simplified model of Vilaça et al. (2017) underestimated the local head losses caused by the start connectors evaluated in the present study. The relative errors of the model of Vilaça et al. (2017) were calculated with the start connectors. In the proposed model, the errors for the cumulative frequencies of 100, 90 and $50 \%$ were respectively 22.1, 14.7 and 10.7\%, and for the model of Vilaça et al. (2017), they were $44.8,40.0$ and $34.6 \%$. The maximum absolute deviation observed between the two models was $1.92 \mathrm{~m}$, which represents a percentage error of $24.5 \%$.

The model for union valve showed the lowest RMSE among all connections tested. For cumulative frequencies of 100,90 and $50 \%$ the relative errors were $32.3,14.3$ and $6.7 \%$, respectively. For the start valves, the corresponding relative errors were $30.0,25.5$ and $16.7 \%$.
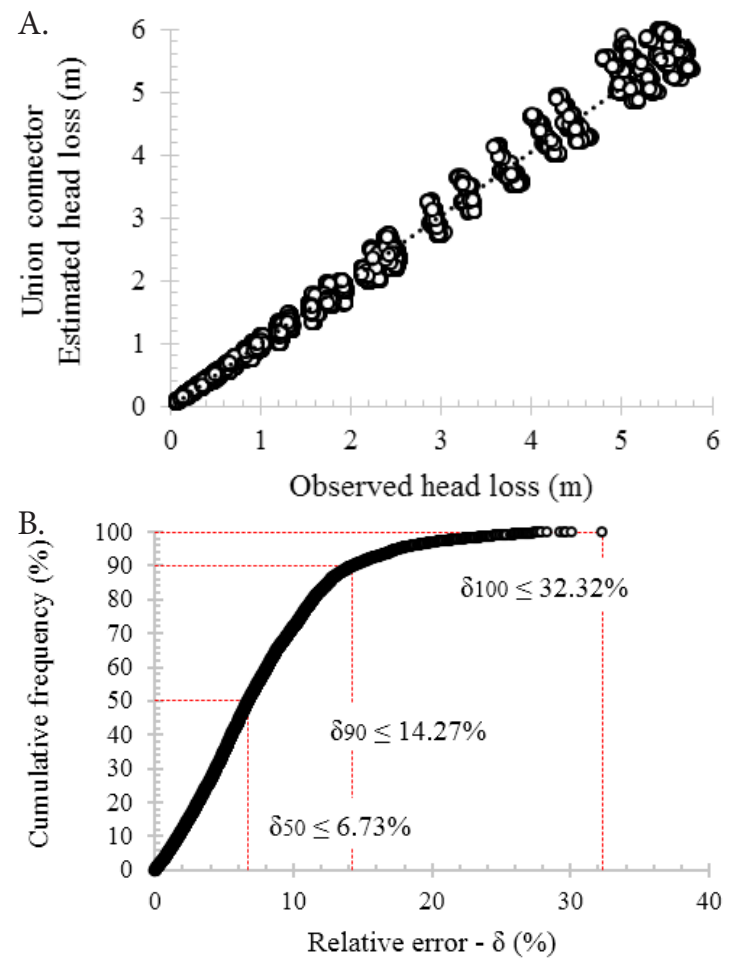

Figure 4. Representation of the simplified dispersion model proposed for union connectors, where (A) local head loss values (observed and simulated), and (B) relative error by cumulative frequency

\section{Conclusions}

1. Local head loss values were expressed by the local head loss coefficient $\left(\mathrm{K}_{\mathrm{L}}\right)$, with values from 2.719 to 24.164 , and are sensitive to the ratio of the internal sections of the connection.

2. Local head loss coefficient was constant for Reynolds numbers above 10,000 . 
3. Flow rate exponents assume values close to the one applied in the Darcy-Weisbach equation $(\mathrm{m}=2)$.

4. The experimental results and the mathematical models developed are useful for hydraulic projects of micro-irrigation systems and projects of hydraulic connections with better geometry, i.e., which cause lower local head loss.

\section{ACKNOWLegments}

The authors thank the RSB Plásticos Ltda. for providing the material used in the experiments.

\section{Literature Cited}

Al-Amoud, A. I. Significance of energy losses due to emitter connections in trickle irrigation lines. Journal of Agricultural Engineering Research, v.60, p.1-5, 1995. https://doi.org/10.1006/ jaer.1995.1090

Ali, M. H.; Abustan, I. A new novel index for evaluating model performance. Journal of Natural Resources and Development, v.4, p.1-9, 2014. https://doi.org/10.5027/jnrd.v4ii0.01

Azevedo Netto, J. M.; Fernández y Fernández, M. Manual de hidráulica. 9.ed. São Paulo: Edgard Blucher, 2015. 631p.

Bombardelli, W. W. A. Perda localizada de carga em conexões utilizadas em sistema de microirrigação. Piracicaba: USP, 2018. 81p. Dissertação Mestrado

Bombardelli, W. W. A.; Camargo, A. P. de; Lavanholi, R.; Araújo, A. C. S.; Talamini Junior, M. V.; Frizzone, J. A. Projeto e validação de uma bancada para ensaios de perda de carga localizada. Irriga, v.edição especial, p.1-10, 2017. https://doi.org/10.15809/ irriga.2017v1n1p1-10

Buckingham, E. On physically similar systems: Illustrations of the use of dimensional equations. Physical Review, v.4, p.345-376, 1914. https://doi.org/10.1103/PhysRev.4.345

Cardoso, G. G. de G.; Klar, A. E. Índice geométrico e perda de carga localizada em conexão de emissores "online". Engenharia Agrícola, v.34, p.1114-1127, 2014. https://doi.org/10.1590/S010069162014000600008

Fox, R. W.; Pritchard, P. J.; McDonald, A. T. Introduction to fluid mechanics. 8.ed. Hoboken: John Wiley \& Sons, 2011. 899p.

Freitas, G. H. S.; Michels, F. S.; Passos, W. E. Análise dimensional e aplicação hidráulica do teorema Pi de Buckingham. Vetor, v.25, p.84-101, 2015.

ISO - International Organization for Standardization. ISO/TR 15155 - Test facilities for agricultural irrigation equipament. Genebra: International Organization for Standardization, 2005. 24p.

ISO - International Organization for Standardization. ISO 9644 - Pressure losses in irrigation valves: Test method. Genebra: International Organization for Standardization, 2008. 11p.
Kotowski, A.; Szewczyk, H.; Ciezak, W. Entrance loss coefficients in pipe hydraulic systems. Environment Protection Engineering, v.37, p.105-117, 2011.

Munson, B. R.; Okiishi, T. H.; Rothmayer, A. P.; Huebsch, W. W.; Rothmayer, A. P. Fundamentals of fluid mechanics. 7.ed. Hoboken: John Wiley \& Sons, 2013. 795p.

Perboni, A.; Frizzone, J. A.; Camargo, A. P. de; Pinto, M. F. Modelling head loss along emitting pipes using dimensional analysis. Engenharia Agrícola, v.35, p.442-457, 2015. https://doi. org/10.1590/1809-4430-Eng.Agric.v35n3p442-457/2015

Prado, G. Decréscimo da energia de pressão devido a instalação de conexões e peças especiais nas tubulações. Enciclopédia Biosfera, v.11, p.2542-2555, 2015.

Provenzano, G.; Pumo, D. Experimental analysis of local pressure losses for microirrigation laterals. Journal of Irrigation and Drainage Engineering, v.130, p.318-324, 2004. https://doi. org/10.1061/(ASCE)0733-9437(2004)130:4(318)

Rettore Neto, O.; Frizzone, J. A.; Miranda, J. H. de; Botrel, T. A. Perda de carga localizada em emissores não coaxiais integrados a tubos de polietileno. Engenharia Agrícola, v.29, p.28-39, 2009. https:// doi.org/10.1590/S0100-69162009000100004

Rocha, H. S. da; Marques, P. A. A.; Camargo, A. P. de; Frizzone, J. A.; Saretta, E. Internal surface roughness of plastic pipes for irrigation. Revista Brasileira de Engenharia Agrícola e Ambiental, v.21, p.143-149, 2017. https://doi.org/10.1590/1807-1929/agriambi. v21n3p143-149

Swamee, P. K. Design of a submarine oil pipeline. Journal of Transportation Engineering, v.119, p.159-170, 1993. https://doi. org/10.1061/(ASCE)0733-947X(1993)119:1(159)

Vekariya, P. B.; Subbaiah, R.; Mashru, H. H. Hydraulic of microtube emitters: A dimensional analysis approach. Irrigation Science, v.29, p.341-350, 2010. https://doi.org/10.1007/s00271-010-0240-6

Vilaça, F. N.; Camargo, A. P. de; Frizzone, J. A.; Mateos, L.; Koech, R. Minor losses in start connectors of microirrigation laterals. Irrigation Science, v.35, p.227-240, 2017. https://doi.org/10.1007/ s00271-017-0534-z

Willmott, C. J.; Robeson, S. M.; Matsura, K. A refined index of model performance. International Journal of Climatology, v.32, p.20882094, 2012. https://doi.org/10.1002/joc.2419

Yildirim, G. An assessment of hydraulic design of trickle laterals considering effect of minor losses. Irrigation and Drainage, v.56, p.399-421, 2007. https://doi.org/10.1002/ird.303

Zitterell, D. B.; Frizzone, J. A.; Rettore Neto, O. Dimensional analysis approach to estimate local head losses in microirrigation connectors. Irrigation Science, v.32, p.169-179, 2013. https://doi. org/10.1007/s00271-013-0424-y

Zitterell, D. B.; Frizzone, J. A.; Rettore Neto, O.; Ullmann, M. N. Perda de carga em microtubos e conectores utilizados em microaspersão. Engenharia Agrícola, v.29, p.591-604, 2009. https://doi.org/10.1590/S0100-69162009000400009 